\title{
Updates to the China Design Standard for Energy Efficiency in Public Buildings
}

\author{
Tianzhen Hong ${ }^{1} *$, Cheng $\mathrm{Li}^{1}$, Da Yan ${ }^{2}$ \\ ${ }^{1}$ Building Technology and Urban Systems Division, \\ Lawrence Berkeley National Laboratory, \\ 1 Cyclotron Road, Berkeley, California 94720, USA \\ ${ }^{2}$ School of Architecture
}

Tsinghua University, Beijing 100084, China

*Corresponding Author: thong@lbl.gov 


\title{
Updates to the China Design Standard for Energy Efficiency in Public Buildings
}

\begin{abstract}
The China Design Standard for energy efficiency in public buildings (GB 50189) debuted in 2005 when China completed the $10^{\text {th }}$ Five-Year Plan. GB 50189-2005played a crucial role in regulating the energy efficiency in Chinese commercial buildings. The standard was recently updated in 2014to increase energy savings targets by $30 \%$ compared with the 2005 standard. This paper reviews the major changes to the standard, includingexpansion of energy efficiency coverage and more stringent efficiency requirements. The paper also discusses the interrelationship of the design standard with China's other building energy standards. Furthermore, comparisonsare made with ASHRAE Standard 90.1-2013 to provide contrasting differences in efficiency requirements. Finally recommendations are provided to guide the future standard revision, focusing on three areas: (1) increasing efficiency requirements of building envelope and HVAC systems, (2) adding a whole-building performance compliance pathway and implementing a ruleset based automatic code baseline model generation in an effort to reduce the discrepancies of baseline models created by different tools and users, and (3) adding inspection and commissioning requirements to ensure building equipment and systems are installed correctly and operate as designed.
\end{abstract}

\section{Keywords}

Building energy standard, building design, China, energy efficiency, GB 50189, public buildings 


\section{Introduction}

The Chinese economy has been growing at nearly $10 \%$ annually for more than two decades. Along with this economy growth the national energy consumption has increased significantly. The total primary energy use in China was 3.25 billion ton coal equivalent $(\mathrm{TCE}, 1 \mathrm{TCE}=29.39 \mathrm{GJ})$ in 2010 , of which $68 \%$ was coal, $19 \%$ for petroleum, $4.4 \%$ for natural gas, and $8.6 \%$ for nuclear, hydroelectric power and wind power (NBS, 2011).China'simport of petroleum is over 50\%(MoLR, 2011). The availability of energy resources has emerged as a challenging issue for Chinese sustainable economicdevelopment and homeland security.

The contemporary building industry, a major engine boosting China's economic development,hasadded up to 60 billion square meters of new buildings since the start of economic reform in 1980s (BECRC, 2012). About 40 billion square meters of new floor space will be built in China by 2025 while urban population in 2030 will be nearly double that of 2000(Woetzel et al., 2009). The buildings sector in China consumed 10\% of the total primary energy in 1978, but has now grown to 20-25\% (BECRC, 2012; Fridley, 2008; Price et al., 2011). According to the "China Road Map for Building Energy Conservation," the total energy use in China should be controlled to under 4 billion TCE per year by 2020, with thetarget for the buildings sector set at1 billion TCE per year (Peng et al., 2013).

Nearly $20 \%$ of new constructionisnon-residential (commercial) buildings (Hong, 2009), including office buildings, schools, hotels, hospitals, retail shops and others. The energy consumption due to the operation of commercial buildings accounts for a significant portion of the total energy use in China, and is expected to increase by over 7\% per year (Fridley, 2008; Zhou, 2007). The energy savings potential in public buildings is estimated to be about $50 \%$ by combining energy conservation measures with improved operations(Hong, 2009).In the“China Road Map for Building Energy Conservation"prescribed for nonresidential buildings,targetshave been set forthe overall energy use intensity to be less than 65.0 $\mathrm{kWh} /\left(\mathrm{m}^{2} \cdot \mathrm{yr}\right)$, with the specific criteria indicating $70 \mathrm{kWh} /\left(\mathrm{m}^{2} \cdot \mathrm{yr}\right)$ for office buildings, $40 \mathrm{kWh} /\left(\mathrm{m}^{2} \cdot \mathrm{yr}\right)$ for schools and $80 \mathrm{kWh} /\left(\mathrm{m}^{2} \cdot \mathrm{yr}\right)$ for hotels (Xiao, 2011; Yang, 2009).

Aiming for sustainable economic growth, the Chinese government and administrative entities have promoted building energy conservation measuresthrough legislative action. Some of this legislation 
includes the 2007 milestone of China's law on energy conservation and two significant regulations in 2013, (1) China's $12^{\text {th }}$ Five-Year Plan for the development of energy conservation, and (2) the new national standard for the energy consumption of buildings. The evolution of the related policies at the national level are shown chronologically in Figure 1.

\section{Figure 1 Recent history of China building energy policies}

Along with the policiesfor energy conservationat a macro level, China's Ministry of Housing and UrbanRural Development (MoHURD) developed building energy standards at a detailed level. Adopted building energy codes dating back to the 1980s included commercial (public) buildings and residential buildings (mostly apartments) in all climate zones except the temperate one. Thesestandardsdefined the efficiency requirements of the building envelope, such as theminimuminsulation of walls, roofs, and floors, thethermal performance of windows, as well as HVAC systems. Absent from these codes were lighting provisions, which weredetailedin a separate regulation (Shui et al., 2009). The objective was to provide a prescriptive compliance path, requiringthe efficient design of building components to meet standard requirements. For the building envelope, a trade-off approach allowed for the performance of opaque envelopes and windows. For the most part, the prescriptive requirements detailed in theChinese standards are slightly less stringent than those in the United States(Mo et al., 2010; Evans et al., 2010).However, similarly to the United States(with national and state code adoption pathways), the Chinese codes are mandatory at the national level, but providelocal governments with the ability to adopt more stringent standards.

For commercial buildings, MoHURD developedstandard GB 50189, to prescribe minimum energy efficiency. GB, in Chinese pinyin "Guo Biao" means national standard. Derived from ahotel-based standardprescribed in the 1980s (Feng et al., 2014), GB 50189 debuted in 2005 with the goal of cutting the building energy consumption by $50 \%$ compared with baseline buildings built in 1980 s. The scope of GB 50189-2005 included offices, hotels, schools and retail buildings and applied to new construction, as well as the expansion and retrofit of the existing public buildings. Serving as the major regulative vehicle since 2005, GB 50189 has successfully fulfilled its initial goals, and has significantly improved the energy 
performance of the public buildings in China (Hong, 2009).In 2014, MoHURD upgraded the standardto pursue furtherenergy savings, targeting an energy reduction of $30 \%$ from 2005 baseline levels.

This paper reviews the major changes in the Standard GB 50189-2014 for public buildings in China. It discusses the relationship of the standard with China's other building energy codes, and compares the efficiency requirements with those in the United States peer standard ASHRAE 90.1-2013: Energy Standard for Buildings Except Low-Rise Residential Buildings (ASHRAE, 2013).Recommended areas of improvementfor GB 50189 in future revisions are also suggested.

\section{Methods}

\subsection{Introduction of the Standard GB50189-2014}

China categorizes its building stock into civil buildings and industrial buildings. The civil buildings are further categorized into residential buildings and public/commercial buildings. The public buildings include officebuildings, schools, hotels, hospitals, retails and others.

The Standard GB 50189-2005 intended to achieve energy savings of 50\% for commercial buildings in China compared to those built in 1980s. Regarding the technical measures, GB 50189-2005featuredtwo major sections on the building envelope and HVAC systems. The general structure of GB 50189-2005is illustrated in Figure 2. Specifically, it prescribedefficiency of the HVAC equipment and thermal performance of the building envelope. The lighting requirements werereferred toanother national Standard GB 50034-2004 Lighting Design of Buildings. The efficiency requirements were dependentupon the building location and climate zones, defined in China Standard GB 50178, "Standard of climatic regionalization for architecture." China has five climate zones: severe cold, cold, hot-summer and coldwinter, hot-summer and warm-winter, andtemperate (Figure 3). A comprehensive review of GB 501892005 , including analysis of coverage of efficiency requirements and comparison with those of ASHRAE Standard 90.1-2004, was done by Hong (2009).

Figure 2 Structure of the Standard GB 50189-2005

Figure 3 China's five climate zones used in the Standard GB 50189 
Arevision of StandardGB50189occurred in 2014 and was based mostly on the feedback from practitioners who adoptedthe standard, as well as research on the actual performance of thebuildings built in compliance with the standard. The motivation forthe codeupgradewas to support China's ambitious national energy saving targets,specifically MoHURD's elevated building energy performance metric by $30 \%$ from the previousrequirements. The major changes to the 2014 standard are summarized in sections 2.1-2.3.

\subsection{Structure}

The standard structure wasextended to cover more technical aspects affecting the building energy performance. The electricity consumed by lighting and appliances has become a major portion of the total energy use in public buildings. Renewable energy has become widely adopted as one way to reduce the net building energy use in China.As shown inFigure 4,the newrequirements are highlighted in bold, includingnew chapterson the electrical system,renewable energy systems, and watersupply and drainage systems. Traditionally,the water supply and drainage systemsconsume significant amounts of electricity and water. Therefore, these new challenging issues require designers and stakeholders to design effectively in order to achieve energy efficient and environmentally friendly buildings. As for the existing envelope section, some additional provisions were added to prescribe the energy-related architectural characteristic, such as the consideration of daylighting and orientation in the very early design phase.In addition, the HVAC section was supplemented with requirements for pipe and duct insulation, and the efficiency of terminal units.

Figure 4 Structure of the Standard GB 50189-2014, with additions highlighted

\subsection{More stringent efficiency requirements}

For the building envelope, GB 50189-2005prescribed the allowable maximum U-factors for exterior walls, roofs, and floors. It also defined the minimum thermal resistance for the slab-on-grade floors, the belowgrade walls, and the maximum U-factors and shading coefficients for windows and skylights (Hong, 2009). The GB 50189-2005 specified the requirements for these technical parameters in all climate zones of China, except the Temperate zone where there is little demand of air conditioning or heating. 
All of the requirements were tightened in terms of energy efficiency in GB 50189-2014. As Table 1 indicates the U-factors and shading coefficients (SCs) are more stringent compared to those in GB 501892005. Additionally, GB 50189-2014 added efficiency requirements for the temperate climate zone.

Moreover, for the envelope tradeoff compliance path, GB 50189-2014 mandated minimal requirements for the envelope U-factor and SC for windows. By prescribing these requirements, GB 50189-2014 drewa bottom line for the tradeoff approach. Finally, the Severe Cold climate zone was divided into three sub zonesinstead of two to allow more appropriate local efficiency requirements.

Table 1 Comparison of the window performance requirements in China's Cold climate zone

For HVAC systems, the prescriptive efficiency requirements were increased in GB 50189-2014. GB 50189-2005 mainly regulated the efficiency,Coefficient of Performance (COP) andIntegrated Part-Load Value (IPLV), of water-cooled and air-cooled chillers. The 2014 updates increased these efficiencies significantly. Table 2 summarizes the chiller efficiency requirements for the cold climate zone. The requirements depend on condenser cooling source (water or air), chiller type (reciprocating/scroll, screw, and centrifugal), and chiller cooling capacity. The chiller efficiency increases are listed in Table 3, with the chiller efficiency requirements dependent on the climate zone, distinctly different from ASHRAE 90.12013. This was based on the consideration that in cooler climates, chillers operate for fewer hours, so the efficiency can be lowered. At first glance this seems reasonable, but actual chiller operation depends on the cooling loads in the building which are influenced by other factors (e.g.internal loads) besides the climate.

Table 2 Comparison of the chiller efficiency for cold climate zone

Table 3 Increases of chiller efficiency

GB 50189-2014 designated a new indicator, the SCOP (System COP), to regulate the efficiency of the entire cooling system. SCOP takes into account chillers, auxiliary equipment (pumps, fans and cooling towers) as well as all terminal units in efficiency calculations. This highlights the fact that GB 50189-2014 considers efficiency requirements to be integrated with design rather than isolated or summed component efficiencies(Li et al., 2014). Table 4 lists all the requirements on SCOP in the Standard GB 50189-2014.

Table 4 Cooling system efficiency SCOP requirements in the Standard GB 50189-2014 
GB 50189-2014 also added efficiency requirements on multi-split air-conditioning and heat pump units. Table 5 shows the IPLV requirements.

Table 5 Requirements of IPLV for multi-split air-conditioners and heat pumps in the GB 50189-2014

\subsection{New requirements in GB 50189-2014}

Hong (2009) recommended adding the following key features to GB 50189-2005 to ensure its coverage as comprehensive as the ASHRAE Standard 90.1:

- Incorporate lighting and HVAC equipment efficiency requirements into the Standard to make it a self-contained standard. Right now the Standard refers to a few other national standards for these requirements. This makes the enforcement and maintenance of the Standard more difficult.

- Define minimum efficiency requirements forexterior lighting and service water heating systems.

- Provide whole building performance compliance method. ASHRAE Standard 90.1 allows the Energy Cost Budget method to tradeoff energy performance among envelope, lighting, service water heating, and HVAC.

- Allow an alternate building-area method for lighting compliance in GB 50034-2004.

- Define requirements of computer modeling tools for code compliance calculations. ASHRAE Standard 90.1 requires compliance calculation engines to be tested in accordance with ASHRAE Standard 140: Standard method of test for the evaluation of building energy analysis computer programs.

- Provide compliance forms, checklist for field inspection. TheStandard should have these forms, rather than relying on localgovernments to develop their own forms during the enforcementof the Standard.

GB 50189-2014 added a new chapter for electrical systems, including lighting system efficiency, electricity monitoring and metering systems. By referencing another national lighting standard, GB 50189-2014 explicitly defined the upper limit of the lighting power density for every type of space in buildings andapplied the space-by-space method to regulate the lighting system. Allowance of the lighting power 
density was defined for each type of space, with every space in the building must comply onits ownlighting requirement. Comparisons betweennew lighting requirements and those in the previous versionsare shown inTable 6 andhighlight theaggressive improvements in lighting power density (LPD).

Table 6 Upper limits of lighting power density (LPD) in the 2005 and 2014 Standard GB 50189

The measurement and monitoring of energy consumption in buildings becomes critical in understanding the actual energy use and to provide feedback to designers and building operators to improve the energy efficiency in buildings. GB 50189-2005 recommended methods of energy monitoring, while in GB 501892014 energy monitoring was mandatory with detailed provisions.

GB 50189-2014 added a chapter on water supply and drainage (plumbing system) and the service hot water system, with the goal to reduce water use as well as water heating energy use. The GB 50189-2014 recommended design approaches, equipment efficiencies and water usage metering. Table 7 and Table 8 show the efficiency requirements of pumps and water heaters.

Table 7 Overall efficiencyrequirements for pumps (impeller and motor)

Table 8 Efficiency requirements for service water heaters

In the current building design procedures, renewable energy systemshave become a solution to balance the energy demand in buildings. To standardize the application of renewable energy and maximize the benefit in utilizing these technologies in buildings, GB 50189-2014 specifically provided guidelines for the renewable energy systems in buildings. Technical provisions covered the use of solar power and ground source heat pumps. Within these provisions, anevaluation ofthe solar resourcewas required prior the detailed design of the photovoltaic system. Also for the ground source heat pump, the standard provided the minimal efficiency for heat pump units.

\section{Results}

\subsection{Stringency analysisof the standard}

All of the aforementioned improvements and amendments in the Standard GB 50189-2014 were driven by the goal of meeting a $30 \%$ energy savings compared to the 2005 standard. A comprehensive code 
stringency analysis of the Standard GB 50189-2014 has not been conducted. Such analysis, as conducted for ASHRAE Standard 90.1 (Halverson et al., 2014), would require energy savings calculations based on whole-building energy simulation for China's entire commercial building stock. To prove efficacy, Feng(2014) conducted a series of energy simulations to compare the energy use of prototypical office buildings that minimally complied with the 2014 and 2005 standards, in three Chinese cities Beijing, Guangzhou, and Shanghai. His calculations showedGB 50189-2014 standard achieved 25\% energy savings (on average) over the 2005 version, slightly lower than the $30 \%$ savings target. The energy savings were $27 \%, 23 \%$ and $24 \%$ for Beijing,Guangzhou,Shanghai, respectively. The prototypical Chinese office buildings Feng used were based on surveys in China and the prototype building models developed by the U.S. Department of Energy (USDOE, 2010).

\subsection{The role of GB50189-2014on China'sbuilding energy regulation system \\ China has gradually alteredthe building energy efficiency policy portfolio, from a purely regulatory approach with a mandatorybuilding code at the initial stage to voluntary green buildings initiatives ( $\mathrm{Li}$ and} Shui, 2015).GB 50189-2014currentlyservesas the principal vehicleguiding the building design from the perspective of energy conservation. It coversall of the energy uses in buildings, including envelope, HVAC system, lighting, plug-loads, water and drainage systems, domestic hot water systems, and renewable energy systems. For detailed prescriptions on specific issues, like lighting and daylighting design, GB 50189 provides general requirements while referencing GB 50033-2013and GB 50034-2013.

In addition to GB 50189-2014,five other standards are included in the standard system leveraged by the Chinese administrative entities. These are namely: (1)GB 50378-2014 "Evaluation standard for Green Buildings"(MoHURD, 2014b), (2)GB 50033-2013 "Standard for daylighting design of buildings"(MoHURD, 2013a), (3)GB 50034-2013 “Standard for lighting design of buildings”(MoHURD, 2013b), (4)JGJ/T 288-2012 “Standard for building energy performance certification”(MoHURD, 2012), and (5) an upcoming GB standard“Standard for energy consumption of buildings”(MoHURD, 2014a).

In China, building rating and labeling programs are widely adopted to promote energy savings in buildings.Correspondingly,GB 50378-2014 "Evaluation standard for Green Buildings" (denoted as the 
green building standard hereafter) is the foremost guide to prescribe the pathway tocertificationfor China's green building three-star rating program. This standard expands the scope of regulation, with provisions on land use, the outdoor environment, energy savings, water savings, material savings, indoor environmental quality, as well as building operation and management.By providing a technical approach for procuring the scores in pursuit of certification, the green building standard builds up a pathway to promote the development of sustainable buildings in China.

Since the building certification program is voluntary, the requirements in the green building standard are optional and only applicable when a certain level of certification is pursued. However even within the voluntary standards such as the GB 50378, there are "mandatory" pre-requisite requirements and optional requirements that the design team may choose to meet, to gain points towards attaining the desired green building rating (Geng et al, 2012).

Within the hierarchical anatomy of the China building standard system, GB 50189-2014 is the foundation whereas the green building standard represents China's vision of holistic building performance.

Even with the design standard for commercial buildings and the green building standard, there is still a strong need for regulations to monitor and control the actual energy use of commercial buildings in China, especially to meet China's aggressive energy savings targets. In this respect, JGJ/T 288-2012 "Standard for building energy performance certification" and the upcoming national standard "Standard for energy consumption of buildings" are twothe major vehicles.

JGJ/T 288-2012 "Standard for building energy performance certification"aims to promote a performance benchmarking system based on the actual energy performance of commercial buildings. Developed by MoHURD, JGJ/T 288-2012 recommends approaches to monitor, normalize, and benchmark, in an effort to evaluate the actual energy use of commercial buildings. Unfortunatelythis voluntary standard has relatively little impact onChina's regulation system and isoften overlook by authorities in government and industry.

The national standard "Standard for energy consumption of buildings," carriesmore responsibility inregulating the actual energy consumption of commercial buildings in China. The standard prescribes two levels of energy use intensity (EUI in $\left.\mathrm{kWh} /\left(\mathrm{m}^{2} \cdot \mathrm{yr}\right)\right)$ based on a national survey of thousands of commercial 
buildings located in major cities in China.The first level provides constraint EUIs that every building should not exceed. The second level provides threshold EUIs detailed specifically for energy efficient buildings. The two levels of EUIs depend on the building type, climate zone, and are normalized by the service level of building (operating hours, number of people, and number of computers etc.). China views this standard as cornerstone legislature to control the actual energy use in buildings and important to achieving the nation's energy and carbon goals.

The hierarchy of China's building energy standards system is illustrated in Figure 5. The top four standards target the efficiency of commercial buildings during the design phase, while the bottom two standards call for the monitoring of actual energy use during the operational phase.

\section{Figure 5 China building energy standards and their relations}

It should be noted that China's building energy standards and regulation system is complex. It is beyond the focus of this study to provide comprehensive description, references (BECRC 2012, Mo et al 2010; Li and Shui 2015; Peng et al 2013; Shui et al 2009) are available for more in-depth information.

\section{Discussion}

\subsection{Comparisons of GB 50189-2014 with ASHRAE Standard 90.1- 2013}

Although ChinaStandard GB 50189-2014 is more stringent than the 2005 standard, there is further room toincrease the efficiency requirements. Table 9 to Table 13 comparethe envelope, lighting and HVAC equipment efficiency requirementsspecified by GB 50189-2014 and ASHRAE Standard 90.1-2013. The requirements for the building envelope inASHRAE Standard 90.1-2013 depend on the construction classification. For example, the regulative parameters for opaque elements, including roofs, walls, floors and doors, are offered for each sub construction type under each major category, as demonstrated inTable 9.The regulative indices include the $\mathrm{U}$-factor of the whole assemblyand the $\mathrm{R}$-value of the insulation layer.

In contrast, GB 50189-2014 regulates the opaque envelope differently. The shape coefficient, defined as the ratio of thebuilding's exterior surface area $\left(\mathrm{m}^{2}\right)$ tothe building's volume $\left(\mathrm{m}^{3}\right)$, is the major variable required for regulating opaque components and is contingent upon the major construction type and different shape coefficients.There are no requirements for sub classes under the major envelope type. Moreover, the 
parameters for roofs, walls, and floors are more lenient than those in 90.1-2013. This reflects the relatively poor market penetration of high-end envelope technologies in China. Materials and technologies with high performance, but low cost, are a necessity in the building envelope market in China.

Table 9 Comparison of opaque envelope requirements in China Standard GB 50189-2014 and ASHRAE Standard 90.1-2013.

In 90.1-2013, the Window-Wall-Ratio (WWR) is restricted to be lower than $40 \%$ if the prescriptive compliance path is used.Like opaque components, window indicators, assembly U-factor and assembly SHGC, are prescribed based on the window frame type and whether a window is operable.It is noteworthy that for the operable metal framed window, there is an extra requirement of compliance for the ratio of VT (Visible Transmittance) to SHGC.This aims to encourage the use of daylight. Standard 90.1-2013 has a separate requirement for U-factor and SHGC of metal framing entrance glass doors.

China's GB50189-2014 regulates window performance in a different way. The WWR is added along with the Shape Coefficient to categorizethe sub class.GB50189-2014 has tightened the requirements for windows with the increase of the WWRcapped at 70\% for prescriptive compliance.Different window types, with the same WWR and Shape Coefficient, will share the same parametric requirements. GB50189 uses Shading Coefficient (SC) instead of Solar Heat Gain Coefficient (SHGC) to prescribe the window performance.

To make straight comparisons, the SC values are converted into SHGC values in Table 10, based on the formula SC $=\mathrm{SHGC} / 0.86$. Notably, requirements for the shading coefficient in GB50189 depend on the window orientation. For most situations, windows on the north facade is not subject to any SC or SHGC regulations, because north facing windows (in the Northern hemisphere) receive reduced direct solar heat gains relative to other orientations. Although difficultto do a direct comparison between the two standards, GB50189-2014 appears to have room for improvementin window performance (e.g. for the non-metal framing and metal framing windows) andcan require lower $\mathrm{U}$-factors.

Table 10Comparison of window requirements in China Standard GB 50189-2014 and U.S. ASHRAE Standard 90.1-2013. 
ASHRAE 90.1-2013 providesthe building area method and the space-by-space method to determine the interior lighting power allowance. The space-by-space method establishes a lighting budget for each space separately, but compliance is determined overall for the building by the sum of the product of the space type area and budgets. Trade-offs are allowed between spaces. Standard GB50189-2014 allows this method, however in a prescriptive requirement approach - each space has to meet its own lighting power requirement.Table 11 compares the interior lighting power quota specified in ASHRAE 90.1-2013 and GB50189-2014. Notably, the maximum allowed lighting power density (LPD) forASHRAE 90.1 is higher than that in the Standard GB50189-2014.In ASHRAE Standard 90.1-2013, both the building area method and the space-by-space methodoffer a simplified method for more flexible design, requiring designersonly to show that the total lighting power is lower than the allowance. The allowance can be determined by multiplyingthe given quota index with the total lighting area. The building area methodis not provided in the GB50189-2014.

Lighting control requirements in ASHRAE 90.1-2013 are more concrete and practical compared with the general requirements in GB50189-2014. ASHRAE90.1-2013 requires automatic daylighting controls for side lighting. Besides, spaces (except LPD less than or equal $8.61 \mathrm{~W} / \mathrm{m}^{2}$ or lighted with high intensity discharge lamps) should be equipped with automatic partial off control to cut the lighting power by $50 \%, 20$ minutes after being unoccupied. GB50189 could add similar requirements in future revisions to save lighting energy use.

Table 11Comparison of LPD requirements in China Standard GB 50189-2014 and U.S. ASHRAE Standard 90.1-2013. ASHRAE Standard 90.1-2013 prescribes minimum efficienciesforHeating, Ventilating and Air Conditioning (HVAC) equipment. Table 12andTable 13list therequirements of chiller efficiency and unitary air-conditioner efficiency for both standards.

Compared with GB 50189-2014, ASHRAE 90.1-2013 requires a higher chiller efficiency, either full-load rated COP or Integrated Part-Load Value (IPLV), by 4\% to 14\% (Table 12).However, GB50189-2014 features a unique requirement for the overall performance of the entire cooling system (including chillers, pumps, and cooling towers)under design conditions through the System COP (SCOP) in Table 4. This echoes emphasis on total system performance in theChina design practice and regulations. 
Table 12Comparison of chiller efficiency requirements in China Standard GB 50189-2014 and the U.S. ASHRAE

\section{Standard 90.1-2013.}

Table 13shows the prescriptive requirements for unitary air conditioners in ASHRAE 90.1-2013 and GB50189-2014. Unlike GB50189-2014 which defines separate requirements for each climate zone, ASHRAE 90.1 has a single set of chiller efficiency requirements across all climate zones. Both standards require higher chiller efficiency for large cooling capacities. ASHRAE 90.1-2013 has finer capacity ranges for water-cooled chillers, which tend to have larger cooling capacity.For unitary direct-expansion units, in general, ASHARE 90.1-2013requires higher efficiency than the standard GB50189-2014, especially for smaller capacity units.

Table 13Comparison of requirements for unitary air conditioners in China Standard GB 50189-2014 and U.S.

ASHRAE Standard 90.1-2013.

In comparison to GB50189-2014, ASHSRAE 90.1-2013 has stricter standards, stressing the controls of the terminal unit, ventilation system, and auxiliary equipment. All ventilation systems are required to be equipped with off-hour controls or to automatically turn offwhen not needed.In addition, demand control ventilation (DCV) is required for spaces larger than $50 \mathrm{~m}^{2}$ with a designed occupancy (for ventilation) of greater than 25 people per $100 \mathrm{~m}^{2}$ of floor area,when the space is served by systems with one or more of air-side economizers, automatic modulating control of outdoor air damper, and designed outdoor airflow greater than 1400L/s. Multiple zone HVAC systems must be equipped with controls that can automatically reset the supply air temperature in response to representative building loads, or to the outdoor air temperature. Supply water temperature is also required to be resettable in response to the representative loads or outdoor air temperature.

\subsection{Code compliance improvements for GB 50189-2014}

GB 50189-2014 offers prescriptive compliance pathways for new building construction and retrofits. All building sub-systems and components must meet prescriptive efficiency requirements.For example, Ufactors of proposed walls and roofs should not exceed the standard U-factors for walls and roofs in corresponding climates. The design lighting power density should not be greater than the prescriptive value and the design chiller efficiency should be equal to or higher than the standard chiller efficiency. For the 
envelope, GB 50189-2014, as well as ASHRAE 90.1-2013, allows for a trade-off compliance path which defines the overall thermal performance of the building envelope considering heat transfer as well as solar heat gains. The trade-off option offers more flexibility for architectural design (e.g. WWR higher than 70\%),balancingthe walls/roofs and windows performance across all orientations. In the trade-off calculations, the area and orientation of envelope stays the same, while the thermal performance varies, such that design values are used in the proposed building calculation while standard values are used in the code baseline building calculations. Such trade-off calculations can be tedious for manual calculations. ASHRAE standard 90.1, up to the 2010 version (ASHRAE, 2010), comes with a tool EnvStd for envelope trade-off compliance calculations.The latest 90.1-2013 uses the COMCheck tool(USDOE, 2014).

GB 50189-2014 does not offer the whole-building performance compliance path, which is crucial to enable integrated design and offer the maximal flexibility of building design enabling trade-off of efficiency across all building components and sub-systems. The main reason China has not implemented the performance based compliance path is due to the complexity of the method, as so many details need to be clearly defined so that energy models of the proposed design and the baselinestandard design can be developed. In the U.S. the trend is to automate the process by creating a ruleset based compliance engine, which takes a proposed building design and creates the baseline standard design/model by interpreting the efficiency requirements and rules defined in the standard in a form of computerized ruleset. This is now implemented for California Building Energy Efficiency Standards Title 24 (CEC, 2013a; CEC, 2013b) using the CBECC-Com (AEC, 2014), California Building Energy Code Compliance (for COMmercial/Nonresidential buildings). With CBECC-Com, code compliance using the performance path can be standardized, streamlined and discrepancies due to energy modelers and compliance tools used can be reduced to minimum.

\subsection{Code development process}

Standard GB 50189-2005 was developed mainly based on the ASHRAE Standard 90.1-2004, including the structure of the standard, and assumptions used in energy modeling to evaluate the energy savings of measures. As there are significant differences between the United States and China in thermal comfort 
criteria, building operations and management, as well as occupant behavior in buildings, simply copying the U.S. assumptions used in developing ASHRAE Standard 90.1 would lead to problems of code stringency, cost effectiveness, and ease of implementation and enforcement of China's code. China has started a large scale survey of occupant comfort, building operations and management, and occupant behavior in both commercial and residential buildings, which will definitely provide good data to improve its code development for the next cycle.

To control air pollution in major cities in China, China is in an urgent move to promote low energy buildings employing passive design features and more occupant interactive operations to reduce energy use in buildings. One big difference between GB 50189 and ASHRAE 90.1 is the provisions of outdoor air ventilation. GB 50189 does not require continuous outdoor air by mechanical ventilation systems to meet actual occupant needs, as required by ASHRAE 90.1 referencing the ASHRAE Standard 62.1: Ventilation for acceptable indoor air quality. Instead, Chinese buildings, even highrise ones, have operable windows and occupants have the culture of opening windows for ventilation if necessary.

The code development in China is well under funded by government, which leads to serious problem of lacking in depth research to support the code development, and even worse the necessary process of public hearing and workshops to get feedback from the public and key stakeholders on revisions to the standards.

\section{Conclusions and Policy Implications}

\subsection{Policy Implications}

In addition to the improvement of prescriptive provisions, integrated design approaches should be gradually adopted into the design process of new buildings. Integrated design involves the collaboration of all stakeholders and the entire design team starting with the initiation of the building project. For this, theintegrative effects of building sub-systems such as envelope, lighting, plug-loads, and HVAC systems, are considered and quantified in the design process. An example of integrative effects include the reduction of lighting power and plug-loads, that will decrease building cooling loads, and thus cooling systems can be downsized, while heating systems have to be upsized. 
Research on certified high performance buildings suggested that technologies can be contributive, but not dictating, to the energy performance of buildings(Diamond, 2006; Li et al., 2014; Newsham et al., 2009; Scofield, 2009). Adding multiple efficient technologies does not necessarily improve building energy performance. Detailed case studies in the research further suggested that other factors, such as occupant behavior and building operation andmaintenance, could have a significant positive role in realizing the expected building energy savings(Li et al., 2014).An integrated design approach that takes into account all of the factors, from technical measures to occupant behavior, offers the greatest potential for delivering a building whose actual performance is energy efficient(Busby Perkins \& Will Stantec Consulting, 2007).

To facilitate with the adoption of integrated design in practice, integrated approaches should be defined and recommended in the design standard. Guidelines recommended byBusby Perkins \& Will Stantec Consulting (2007) and Li et al. (2014) are worth considering and bulleted as follow:

1. Learn the occupant culture and actively use it for natural ventilation, daylighting and other energyrelated technologies.

2. Select most suitable technologies based on climate

3. Value the consultancy from the building owner, prospective tenants, and operating team, for their expecting features of the building, operation practice and maintenance routines.

Inspection provisions are one method to ensure compliance. ASHRAE Standard 90.1-2013 has provisions on inspection for the (1) wall insulation, after the insulation and vapor retarder arein place but before concealment, (2) roof/ceiling insulation, after roof/insulation is in placebut before concealment, (3) slab/foundation wall, after slab/foundation insulation isin place but before concealment, (4) fenestration, after all glazing materials are in place, (5) continuous air barrier, after installation but before concealment, (6) mechanical systems and equipment and insulation afterinstallation but before concealment, (7) electrical equipment and systems after installation butbefore concealment.

ASHRAE Standard 90.1-2013 also requires the commissioning of HVAC systems. HVAC control systems shall be tested to ensure that control elements are calibrated, adjusted, and in proper working condition. For projects larger than 50,000 $\mathrm{ft}^{2}\left(4,645 \mathrm{~m}^{2}\right)$ of conditioned area (except warehouses and semi-heated spaces), 
Informative Appendix E of 90.1-2013 references standards that provide detailed instructions for commissioning HVAC systems.China Standard GB 50189-2014 still lacks such inspection or commissioning requirements, which are critical to ensure materials, equipment and systems are installed correctly and operate as designed.

In addition, measures can be investigated to advance building energy performance as suggested by Feng et al. (2014) including (1) measures to encourage shading and natural ventilation for buildings in hot-summer and warm-winter climate zone, (2) measures to improve air-tightness of buildings, (3) measures of automatic dimming control with daylighting, (4) air-side economizers for cooling systems (although outdoor air quality has to be resolved first), (5) measures that credit positive occupant energy behavior, and (6) measures enabling better building operations and energy management.

Code compliance enforcement is the key to achieving the energy savings expected in the new GB 501892014 standard. The construction regulating committee of each city is in charge of verifying the compliance and issuing the certification for projects, with MOHURD, the major administrative entity in China, acting as the primary governing entity. For greater enforcement, clear procedures of field verification (e.g. wall/roof insulation, window labels) and acceptance testing (e.g. of HVAC systems and controls) need to be developed and included in the standard as mandatory requirements. Commissioning is another area to consider for new construction as well as renovations. In addition,consistency among various standards (usually developed by different government agencies with limited coordination) should be required to avoid public confusion, ease of implementation and enforcement by code officials.

Furthermore, as pointed out by Li and Shui (2015), there are a number of outstanding challenges in theway forward in China's promotion of energy-efficient buildings,including insufficient local regulatory and financial support, difficultiesin financing building retrofit, the discrepancy of building energy efficiency (BEE)implementation progress across regions, slow progress on heatreform (moving from local coal-fire boilers to district heating, and moving from charge based on floor area to actual energy use), and also the enormous scale of promoting building energyefficiency in rural areas that has only just begun. BEE policydevelopment in rural areas has largely been left behind at theexpense of the welfare of more than 200 
million households inrural China. This poses a big challenge for financing andbuilding industry skill training.Due to a combination of factors including continued economicgrowth, rising standards of living, and the annual addition of billionsof square meters of new buildings, China's total building energyuse will certainly continue to increase. Ensuring high energyefficiency standards for new construction may allow China toachieve its greatest potential for energy savings and GHG emissions reduction.

\subsection{Conclusions}

The 2014 revision of the ChinaStandard GB 50189 increases the energy efficiency requirements of commercial buildings in China, targeting a 30\% energy savings compared with the 2005 standard. GB 50189-2014 adds requirements of electrical systems, plumbing systems, and renewable energy generation. Suggestions for future revisions to GB 50189-2014 are recommended as follows: (1) increasing efficiency requirements of building envelope and HVAC systems, (2) adding a whole-building performance compliance pathway and implementing a ruleset based automatic code baseline model generation in an effort to reduce the discrepancies of baseline models created by different tools and users, and (3) adding inspection and commissioning requirements to ensure building equipment and systems are installed correctly and operate as designed.

\section{Acknowledgement}

This work was sponsored by the United States Department of Energy (Contract No. DE-AC0205CH11231), and the China Ministry of Housing and Urban-Rural Development and the Ministry of Science \& Technology (Grant No. 2010DFA72740-02) under the U.S.-China Clean Energy Research Center for Building Energy Efficiency.The authors appreciated Sarah C. Taylor-Lange of LBNL for the language edits.

\section{References}

AEC(Architectural Energy Corporation), 2014. CBECC-Com Nonresidential Compliance Software. <http://bees.archenergy.com/ > 
ASHRAE, 2010. 90.1 User's Manual ANSI/ASHRAE/IESNA Standard 90.1-2010. American Society of Heating,Refrigerating and Air-Conditioning Engineers, Atlanta, GA.

ASHRAE, 2013. ANSI/ASHRAE/IESNA Standard 90.1-2013. American Society of Heating,Refrigerating and Air-Conditioning Engineers, Atlanta, GA.

BECRC(Building Energy Conservation Research Center, Tsinghua University), 2012. Annual Report on the Development of Building Energy Saving in China 2012. Building Energy Research Center, Beijing China.

BPWSC(Busby Perkins \&Will Stantec Consulting), 2007. Roadmap for the integrated design process. < http://www.greenspacencr.org/events/IDProadmap.pdf >

CEC(California Energy Comission), 2013a. 2013 Building Energy Efficiency Standards Approved Computer Compliance Programs.<http://www.energy.ca.gov/title24/2013standards/2013_computer_prog_list.html>

CEC(California Energy Comission), 2013b. Title 24, Part 6, of the California Code of Regulations: California's Energy Efficiency Standards for Residential and Nonresidential Buildings. California Energy Commission, Sacramento, CA.

Diamond, R., 2006. Evaluating the energy performance of the first generation of LEED-certified commercial buildings, , the American Council for An Energy-Efficient Economy (ACEEE) 2006 Summer Study on Energy Efficiency. The American Council for an Energy-Efficient Economy, Pacific Grove, CA.

Evans, M., Shui, B., Halverson, M.A., Delgado, A., 2010. Enforcing Building Energy Codes in China: Progress and Comparative Lessons. Pacific Northwest National Laboratory.

Feng, W., Huang, K., Levine, M., Zhou,N., Zhang, SC., 2014. Evaluation of Energy Savings of the New Chinese Commercial Building Energy Standard, the American Council for An Energy-Efficient Economy (ACEEE) 2014 Summer Study on Energy Efficiency. The American Council for an EnergyEfficient Economy, Pacific Grove, CA. 
Fridley, D.G., 2008. Estimating total energy consumption and emissions of China's commercial and office buildings. Lawrence Berkeley National Laboratory.

Geng, Y., Dong, H., Xue, B., Fu, J., 2012. An overview of Chinese green building standards. Sustainable Development 20, 211-221.

Halverson, M., Rosenberg, M., Hart, R., Richman, E., Athalye, R., Winiarski, D., 2014. ANSI/ASHRAE/IES Standard 90.1-2013 Preliminary Determination: Qualitative Analysis. Pacific Northwest National Laboratory, Richland WA.

Hong, T., 2009. A close look at the China Design Standard for Energy Efficiency of Public Buildings. Energy and Buildings 41, 426-435.

Li, C., Hong, T., Yan, D., 2014. An insight into actual energy use and its drivers in high-performance buildings. Applied Energy 131, 394-410.

Li, J. and Shui, L., 2015. A comprehensive analysis of building energy efficiency policies in China: status quo and development perspective. Cleaner Production 90, 326-344.

Mo, K., Burt, L., Hao, B., Cheng, J., Burr, A., Kemkar, S., 2010. Comparative Analysis of U.S. and China Building Energy Rating and Labeling Systems, the American Council for An Energy-Efficient Economy (ACEEE) 2014 Summer Study on Energy Efficiency. The American Council for an EnergyEfficient Economy, Pacific Grove, CA.

MoC(Ministry of Construction, China), 1993. Energy Conservation Design Standard on Building Envelope and Air Conditioning for Tourist Hotels. China Architecture and Building Press, Beijing.

MoHURD (Ministry of Housing and Urban-Rural Development, China), 2012. Standard for Building Energy Performance Certification JGJ/T 288-2012. China Architecture and Building Press, Beijing.

MoHURD (Ministry of Housing and Urban-Rural Development, China), 2013a. Standard for Daylighting Design of Buildings GB50033-2013. China Architecture and Building Press, Beijing. 
MoHURD (Ministry of Housing and Urban-Rural Development, China), 2013b. Standard for Lighting Design of Buildings GB50034-2013. China Architecture and Building Press, Beijing.

MoHURD (Ministry of Housing and Urban-Rural Development, China), 2014a. Standard for Energy Consumption of Buildings (Final for approval). Ministry of Hoursing and Urban-rural Development, China P.R, Beijing.

MoHURD (Ministry of Housing and Urban-Rural Development, China), 2014b. Evaluation Standard for Green Buildings. China Architecture and Building Press, Beijing.

MoLR (Ministry of Land and Resource, China), 2011. Bulletin of the Chinese Land and Resources.

Newsham, G.R., Mancini, S., Birt, B.J., 2009. Do LEED-certified buildings save energy? Yes, but.... Energy and Buildings 41, 897-905.

Peng, C., Yan, D., Jiang, Y., 2013. China Road Map for Building Energy Conservation. Transition to Renewable Energy Systems, 891-911.

Price, L., Levine, M.D., Zhou, N., Fridley, D., Aden, N., Lu, H., McNeil, M., Zheng, N., Qin, Y., Yowargana, P., 2011. Assessment of China's energy-saving and emission-reduction accomplishments and opportunities during the 11th Five Year Plan. Energy Policy 39, 2165-2178.

Scofield, J.H., 2009. Do LEED-certified buildings save energy? Not really.... Energy and Buildings 41, 1386-1390.

Shui, B., Evans, M., Lin, H., Jiang, W., Liu, B., Song, B., Somasundaram, S., 2009. Country Report on Building Energy Codes in China. Pacific Northwest National Laboratory Springfield, VA.

NBS(National Bureau of Statistics, China), 2011. China statistical yearbook. China Statistics Press, Beijing p.2009.

USDOE(U.S. Department of Energy), 2010. ASHRAE 90.1 Commercial Prototype Building Models.<http://www.energycodes.gov/commercial-prototype-building-models > 
USDOE(U.S. Department of Energy), 2014. Commercial Compliance Using

Comckeck.<https://www.energycodes.gov/comcheck>

Woetzel, J., Mendonca, L., Devan, J., Negri, S., Hu, Y., Jordan, Luke, Li, X., Maasry, A.,Tsen, G., Yu, F., 2009. Preparing for China's Urban Billion (McKinsey GlobalInstitute report).

Xiao, H., 2011. Study on Distribution Features and Influencing Factors on Energy Use in Office Buildings by Statistical Method and Survey. Tsinghua University.

Yang, X., 2009. Study of China's building energy efficiency based on energy data. Tsinghua University.

Zhou, N., 2007. Energy use in commercial building in China: Current situation and future scenarios. 8th ECEEE Summer Study, Lawrence Berkeley National Laboratory, 1065-1071. 


\section{List of figures and their captions}

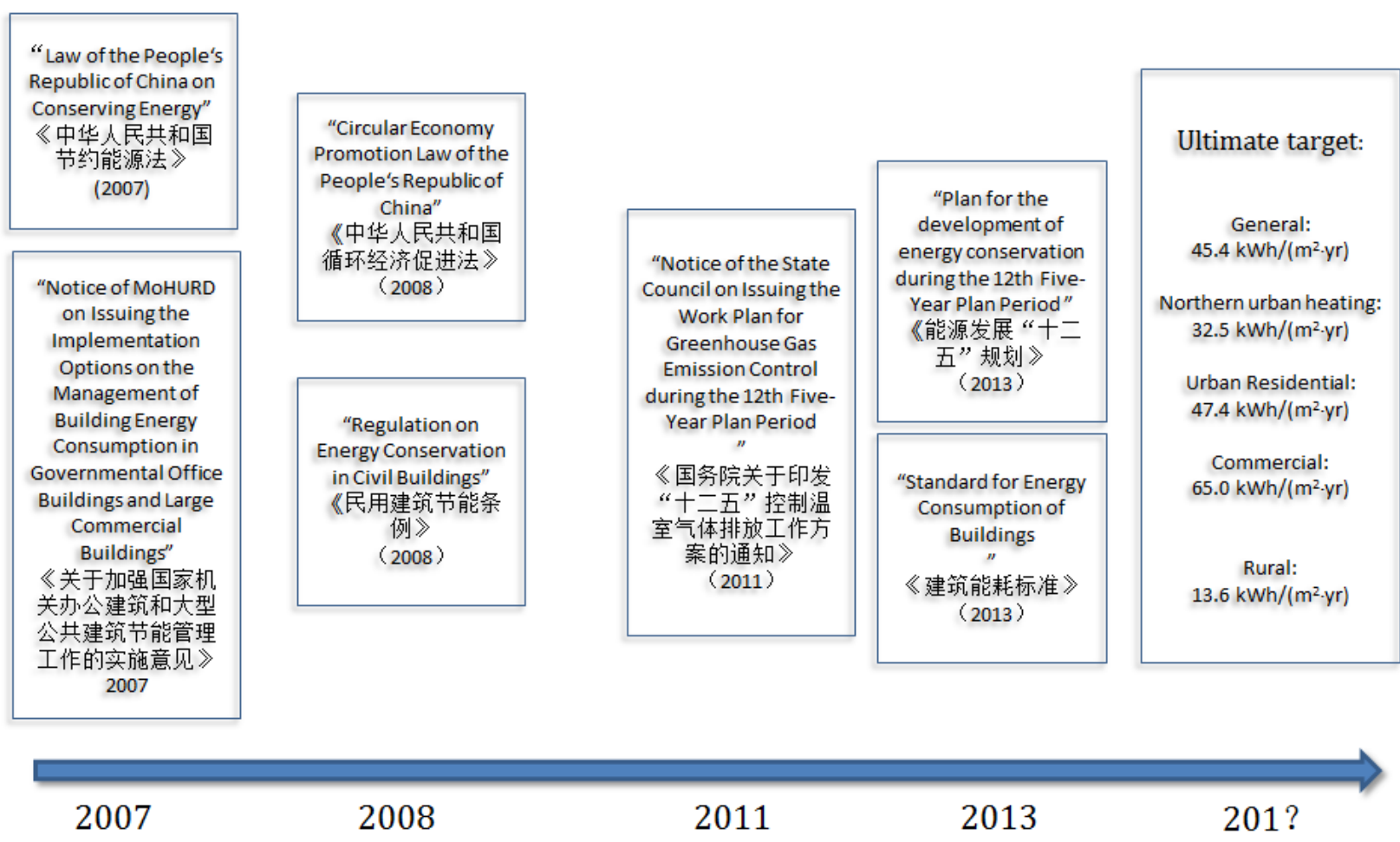

Figure 1 Recent history of China building energy policies

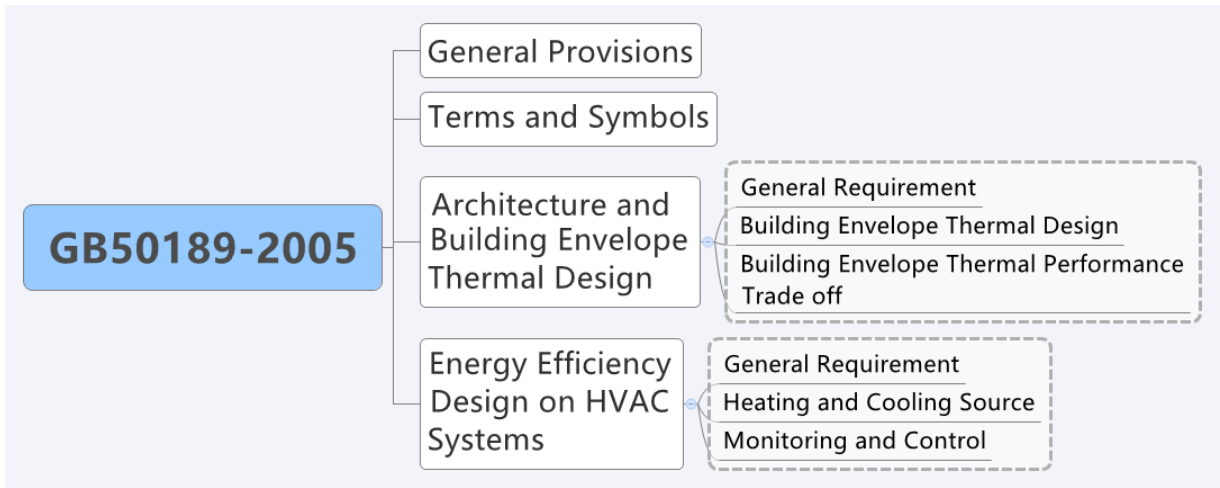

Figure 2 Structure of the Standard GB 50189-2005 


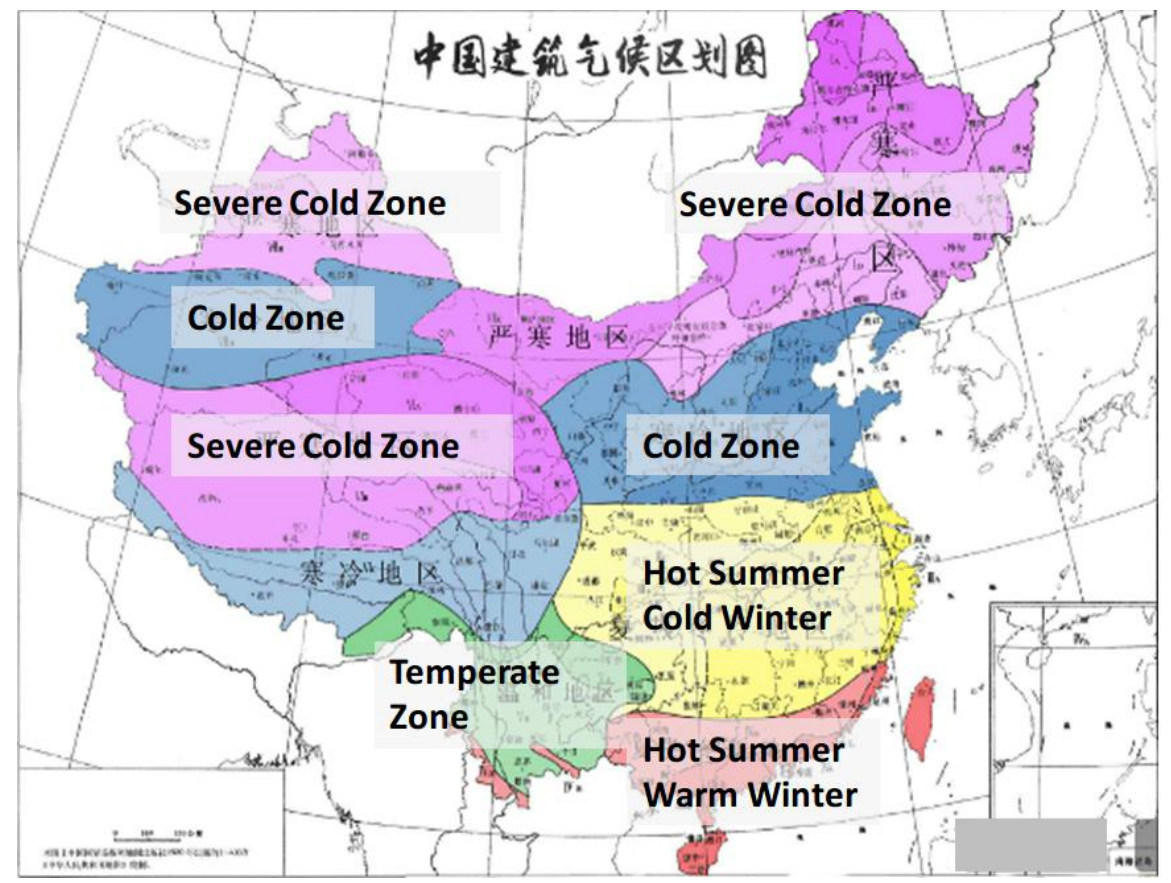

Figure 3 China's five climate zones used in the Standard GB 50189

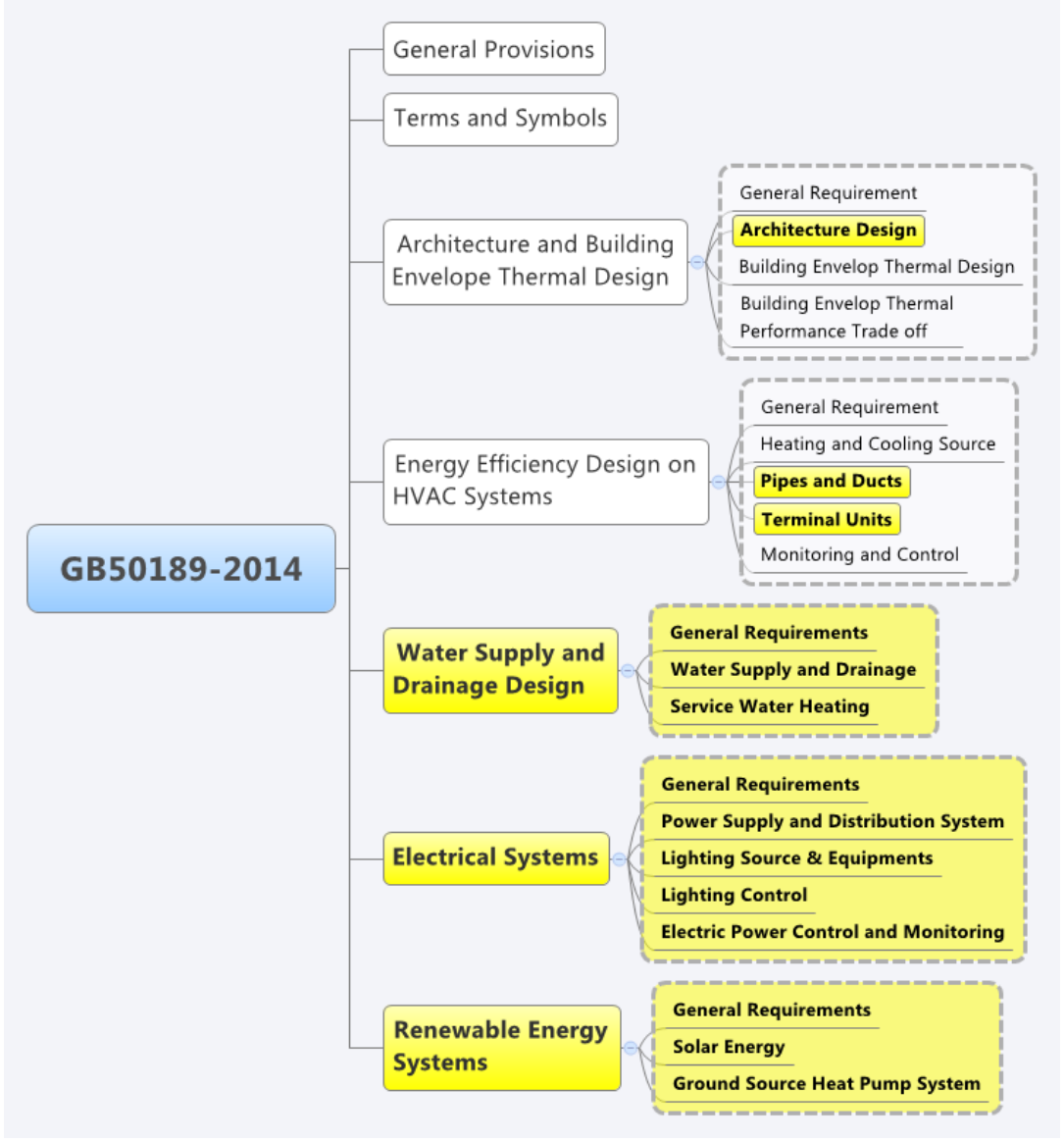

Figure 4 Structure of the Standard GB 50189-2014, with additions highlighted 

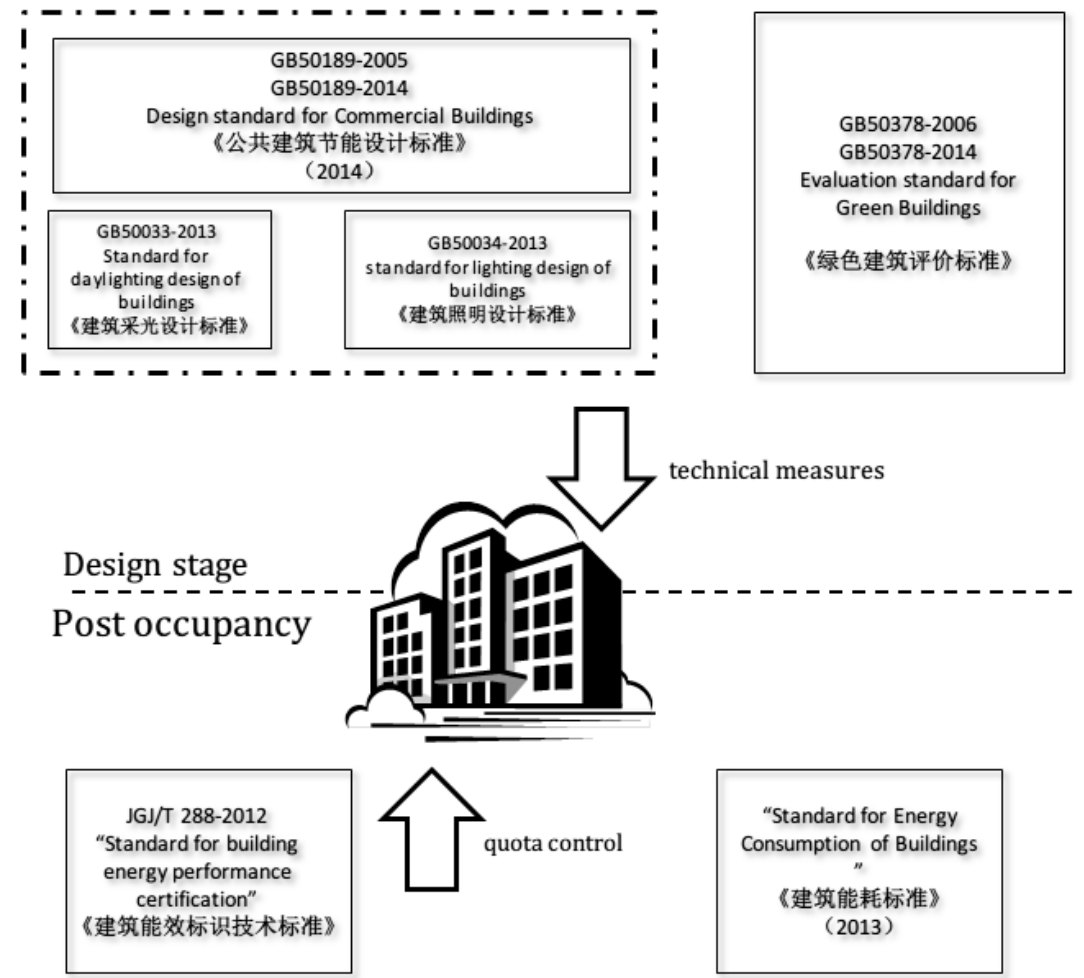

Figure 5 China building energy standards and their relations 


\section{List of Tables and their captions}

Table 1 Comparison of the window performance requirements in China's Cold climate zone

\begin{tabular}{ccccc|cccc}
\hline & \multicolumn{4}{c}{ GB50189 - 2005 } & \multicolumn{4}{c}{ GB50189-2014 } \\
\cline { 2 - 9 } WWR & \multicolumn{2}{c}{ Shape Coeffient $\leq 0.3$} & $0.3<$ Shape Coeffient $\leq 0.4$ & \multicolumn{2}{c}{ Shape Coeffient $\leq 0.3$} & $0.3<$ Shape Coeffient $\leq 0.4$ \\
\cline { 2 - 9 } & U-factor & $\begin{array}{c}\mathrm{SC} \\
\left(\mathrm{W} / \mathrm{m}^{2} \mathrm{~K}\right)\end{array}$ & $\begin{array}{c}\mathrm{E}, \mathrm{S}, \mathrm{W} / \mathrm{N}) \\
\left(\mathrm{W} / \mathrm{m}^{2} \mathrm{~K}\right)\end{array}$ & $\begin{array}{c}\mathrm{SC} \\
(\mathrm{E}, \mathrm{S}, \mathrm{W} / \mathrm{N})\end{array}$ & $\begin{array}{c}\text { U-factor } \\
\left(\mathrm{W} / \mathrm{m}^{2} \mathrm{~K}\right)\end{array}$ & $\begin{array}{c}\mathrm{SC} \\
(\mathrm{E}, \mathrm{S}, \mathrm{W} / \mathrm{N})\end{array}$ & $\begin{array}{c}\text { U-factor } \\
\left(\mathrm{W} / \mathrm{m}^{2} \mathrm{~K}\right)\end{array}$ & $\begin{array}{c}\mathrm{SC} \\
(\mathrm{E}, \mathrm{S}, \mathrm{W} / \mathrm{N})\end{array}$ \\
\hline \hline$\leq 0.2$ & $\leq 3.5$ & - & $\leq 3.0$ & - & $\leq 3.0$ & - & $\leq 3.0$ & - \\
$0.2-0.3$ & $\leq 3.0$ & - & $\leq 2.5$ & - & $\leq 2.7$ & $\leq 0.60 /-$ & $\leq 2.5$ & $\leq 0.60 /-$ \\
$0.3-0.4$ & $\leq 2.7$ & $\leq 0.70 /-$ & $\leq 2.3$ & $\leq 0.70 /-$ & $\leq 2.4$ & $\leq 0.55 /-$ & $\leq 2.2$ & $\leq 0.55 /-$ \\
$0.4-0.5$ & $\leq 2.3$ & $\leq 0.60 /-$ & $\leq 2.0$ & $\leq 0.60 /-$ & $\leq 2.2$ & $\leq 0.50 /-$ & $\leq 2.0$ & $\leq 0.50 /-$ \\
$0.5-0.6$ & $\leq 2.0$ & $\leq 0.50 /-$ & $\leq 1.8$ & $\leq 0.50 /-$ & $\leq 2.0$ & $\leq 0.45 /-$ & $\leq 1.8$ & $\leq 0.45 /-$ \\
$0.6-0.7$ & $\leq 2.0$ & $\leq 0.50 /-$ & $\leq 1.8$ & $\leq 0.50 /-$ & $\leq 2.0$ & $\leq 0.40 / 0.70$ & $\leq 1.8$ & $\leq 0.40 / 0.70$ \\
\hline
\end{tabular}

SC: Shading Coefficient. SC = SHGC / 0.86, SHGC: Solar Heat Gain Coefficient

Table 2 Comparison of the chiller efficiency for cold climate zone

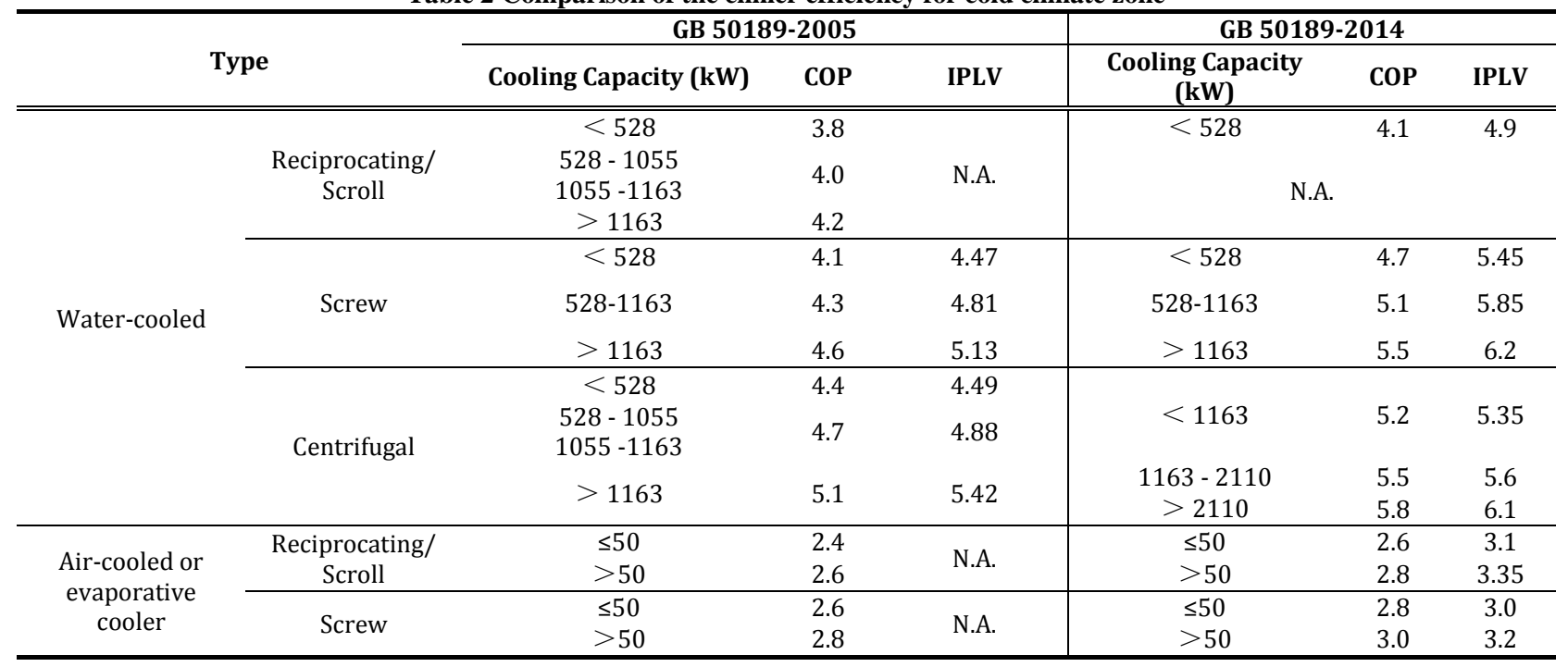

Table 3 Increases of chiller efficiency

\begin{tabular}{cc}
\hline Climate zone & Improvement by percentage \\
\hline \hline Severe Cold A/B & $9.7 \%$ \\
Temperate & $11.5 \%$ \\
Severe Cold C & $12.4 \%$ \\
Cold & $22.1 \%$ \\
Hot-Summer \& Cold-Winter & $30.1 \%$ \\
Hot-Summer \& Warm-Winter & $36.3 \%$ \\
\hline
\end{tabular}


Table 4 Cooling system efficiency SCOP requirements in the GB 50189-2014

\begin{tabular}{|c|c|c|c|c|c|c|c|c|}
\hline & \multirow[b]{2}{*}{ Type } & \multirow[b]{2}{*}{$\begin{array}{l}\text { Cooling } \\
\text { Capacity } \\
\text { (kW) }\end{array}$} & \multicolumn{6}{|c|}{$\operatorname{SCOP}(\mathrm{W} / \mathrm{W})$} \\
\hline & & & $\begin{array}{c}\text { Severe } \\
\text { Cold } \\
\text { A/B }\end{array}$ & $\begin{array}{l}\text { Severe } \\
\text { Cold } \\
\text { C }\end{array}$ & $\begin{array}{c}\text { Temperate } \\
\text { Zone }\end{array}$ & Cold Zone & $\begin{array}{c}\text { Hot } \\
\text { Summer } \\
\text { Cold } \\
\text { Winter } \\
\end{array}$ & $\begin{array}{c}\text { Hot } \\
\text { Summer } \\
\text { Warm } \\
\text { Winter } \\
\end{array}$ \\
\hline \multirow{7}{*}{$\begin{array}{l}\text { Water- } \\
\text { cooled }\end{array}$} & $\begin{array}{c}\text { Reciprocating/ } \\
\text { Scroll }\end{array}$ & $<528$ & 3.3 & 3.3 & 3.3 & 3.3 & 3.4 & 3.4 \\
\hline & \multirow{3}{*}{ Screw } & $<528$ & 3.6 & 3.6 & 3.6 & 3.6 & 3.6 & 3.7 \\
\hline & & $528-1163$ & 4.0 & 4.0 & 4.0 & 4.0 & 4.1 & 4.1 \\
\hline & & $\geq 1163$ & 4.0 & 4.4 & 4.2 & 4.4 & 4.4 & 4.4 \\
\hline & \multirow{3}{*}{ Centrifugal } & $<1163$ & 4.0 & 4.0 & 4.0 & 4.1 & 4.1 & 4.2 \\
\hline & & $1163-2110$ & 4.1 & 4.2 & 4.2 & 4.4 & 4.4 & 4.5 \\
\hline & & $\geq 2110$ & 4.5 & 4.5 & 4.5 & 4.5 & 4.6 & 4.6 \\
\hline \multirow{4}{*}{$\begin{array}{l}\text { Air-cooled or } \\
\text { evaporative } \\
\text { cooler }\end{array}$} & \multirow{2}{*}{$\begin{array}{c}\text { Reciprocating/ } \\
\text { Scroll }\end{array}$} & $\leq 50$ & 2.6 & 2.6 & 2.6 & 2.6 & 2.7 & 2.8 \\
\hline & & $>50$ & 2.8 & 2.8 & 2.8 & 2.8 & 2.9 & 3.0 \\
\hline & \multirow{2}{*}{ Screw } & $\leq 50$ & 2.7 & 2.7 & 2.7 & 2.8 & 2.9 & 3.0 \\
\hline & & $>50$ & 2.9 & 2.9 & 2.9 & 3.0 & 3.0 & 3.0 \\
\hline
\end{tabular}

Table 5 Requirements of IPLV for multi-split air-conditioners and heat pumps in the GB 50189-2014

\begin{tabular}{|c|c|c|c|c|c|c|}
\hline \multirow[b]{2}{*}{$\begin{array}{l}\text { Cooling Capacity } \\
\text { (kW) }\end{array}$} & \multicolumn{6}{|c|}{ IPLV (C) } \\
\hline & Severe Cold A/B & $\begin{array}{c}\text { Severe Cold } \\
\text { C }\end{array}$ & $\begin{array}{c}\text { Temperate } \\
\text { Zone }\end{array}$ & Cold Zone & $\begin{array}{l}\text { Hot-Summer } \\
\text { Cold-Winter }\end{array}$ & $\begin{array}{l}\text { Hot-Summer } \\
\text { Warm-Winter }\end{array}$ \\
\hline$\leq 28$ & 3.80 & 3.85 & 3.85 & 3.90 & 4.00 & 4.00 \\
\hline $28-84$ & 3.75 & 3.80 & 3.80 & 3.85 & 3.95 & 3.95 \\
\hline$\geq 84$ & 3.65 & 3.70 & 3.70 & 3.75 & 3.80 & 3.80 \\
\hline
\end{tabular}

Table 6 Upper limits of lighting power density (LPD) in the 2005 and 2014 standard GB 50189

\begin{tabular}{|c|c|c|}
\hline & GB50189-2005 & GB 50189-2014 \\
\hline & $\mathrm{LPD}\left(\mathrm{W} / \mathrm{m}^{2}\right)$ & $\mathrm{LPD}\left(\mathrm{W} / \mathrm{m}^{2}\right)$ \\
\hline \multicolumn{3}{|l|}{ Office buildings } \\
\hline Office room & 11 & 9 \\
\hline Conference room & 11 & 9 \\
\hline High-class office room & 18 & 15 \\
\hline \multicolumn{3}{|l|}{ Hotels } \\
\hline Guest room & 15 & 7 \\
\hline Lobby & 15 & 9 \\
\hline \multicolumn{3}{|l|}{ Schools } \\
\hline Class room & 15 & 9 \\
\hline$L a b$ & 11 & 9 \\
\hline \multicolumn{3}{|l|}{ Hospitals } \\
\hline Exam / treatment & 18 & 15 \\
\hline Operating room & 30 & 30 \\
\hline Ward room & 6 & 5 \\
\hline Nurse station & 11 & 9 \\
\hline Pharmacy & 20 & 15 \\
\hline
\end{tabular}

Table 7 Overall efficiency requirements for pumps (impeller and motor) in the GB 50189-2014

\begin{tabular}{|c|c|c|c|}
\hline \multicolumn{2}{|c|}{ Single Suction Pump } & \multicolumn{2}{|c|}{ Multiple Level Single Suction Pump } \\
\hline Flow rate $\left(\mathrm{m}^{3} / \mathrm{h}\right)$ & Efficiency (\%) & Flow rate $\left(\mathrm{m}^{3} / \mathrm{h}\right)$ & Efficiency (\%) \\
\hline $7.5-15$ & 51 & $15-22$ & 58 \\
\hline $15-30$ & 59 & $30-42$ & 63 \\
\hline $30-60$ & 66 & $62-80$ & 68 \\
\hline $60-120$ & 75 & $72-108$ & 68 \\
\hline $120-240$ & 79 & $119-191$ & 71 \\
\hline
\end{tabular}


Table 8 Efficiency requirements for service water heaters in the GB 50189-2014

\begin{tabular}{|c|c|c|c|}
\hline Heating Capacity (kW) & Heating Type & $\begin{array}{c}\text { COP for } \\
\text { Normal Type Heater }(W / W)\end{array}$ & $\begin{array}{c}\text { COP for Low Supply } \\
\text { Temperate Type Heater } \\
\text { (W/W) }\end{array}$ \\
\hline \multirow{3}{*}{$<10$} & "One-time heated* & 4.40 & 3.60 \\
\hline & Cycling heated** & 4.40 & 3.60 \\
\hline & Static heated ${ }^{* * *}$ & 4.00 & - \\
\hline \multirow{3}{*}{$>10$} & One-time heated & 4.40 & 3.70 \\
\hline & Cycling heated without Pump & 4.40 & 3.70 \\
\hline & Cycling heated with Pump & 4.30 & 3.60 \\
\hline
\end{tabular}

*One-time heated heater lifts the water temperature directly to the set point;

**Cycling heated heater lifts the water temperature in cycle, water temperature increases to a certain extent in each loop;

*** Static heated heater is a type that water is stored in a tank when being heated.

Table 9 Comparison of opaque envelope requirements in China standard GB 50189-2014 and ASHRAE standard 90.1-2013.

\begin{tabular}{|c|c|c|c|c|c|}
\hline \multicolumn{3}{|c|}{ ASHRAE 90.1-2013 / Climate Zone 5} & \multirow{2}{*}{\multicolumn{3}{|c|}{$\begin{array}{c}\text { GB 50189-2014 / Cold Zone } \\
\text { Maximum U-factor }\left(\mathbf{W} / \mathbf{m}^{2} \mathbf{K}\right)\end{array}$}} \\
\hline \multirow[b]{2}{*}{ Construction type } & \multirow{3}{*}{$\begin{array}{c}\text { Assembly } \\
\text { maximum } \mathbf{U}- \\
\text { factor }\left(W / \mathbf{m}^{2} \mathbf{K}\right)\end{array}$} & \multirow{2}{*}{$\begin{array}{c}\text { Insulation } \\
\text { minimum } R- \\
\text { value }\left(\mathbf{m}^{2} \mathbf{K} / \mathbf{W}\right)\end{array}$} & & & \\
\hline & & & & $\begin{array}{c}\text { Shape } \\
\text { Coefficient } \leq 0.3\end{array}$ & $\begin{array}{c}0.3<\text { Shape Coefficient } \\
\leq 0.4\end{array}$ \\
\hline Roofs & & & & & \\
\hline $\begin{array}{l}\text { Insulation Entirely above } \\
\text { Deck } \\
\text { Metal Building } \\
\text { Attic and other } \\
\text { Walls, above Grade }\end{array}$ & $\begin{array}{l}0.184 \\
0.210 \\
0.119\end{array}$ & $\begin{array}{l}5.3 \text { c.i. } * \\
3.3 \\
8.6\end{array}$ & Roofs & 0.45 & 0.40 \\
\hline $\begin{array}{l}\text { Mass } \\
\text { Metal Building } \\
\text { Steel Framed } \\
\text { Wood Framed and Other }\end{array}$ & $\begin{array}{l}0.513 \\
0.286 \\
0.315 \\
0.291\end{array}$ & $\begin{array}{l}2.0 \text { c.i. } \\
3.3 \text { c.i. } \\
2.3 \\
3.3\end{array}$ & Walls & 0.50 & 0.45 \\
\hline $\begin{array}{l}\text { Wall, below Grade } \\
\text { Below Grade Wall }\end{array}$ & $\begin{array}{c}0.678 \\
\text { (C-factor)** }\end{array}$ & 1.3 c.i. & & & \\
\hline $\begin{array}{l}\text { Floors } \\
\quad \text { Mass } \\
\text { Steel Joist } \\
\text { Wood Framed and Other }\end{array}$ & $\begin{array}{l}0.321 \\
0.214 \\
0.188\end{array}$ & $\begin{array}{l}2.6 \mathrm{c} . \mathrm{i} . \\
5.3 \\
6.7\end{array}$ & $\begin{array}{c}\text { Floors } \\
\text { (Above grade) }\end{array}$ & 0.50 & 0.45 \\
\hline $\begin{array}{l}\text { Slab-on-grade Floors } \\
\text { Unheated } \\
\text { Heated }\end{array}$ & $\begin{array}{c}1.263 \\
\text { (F-factor)*** } \\
1.765 \text { (F-factor) }\end{array}$ & 2.6 & $\begin{array}{c}\text { Slab-on- } \\
\text { grade Floors }\end{array}$ & 0.50 & 0.45 \\
\hline $\begin{array}{l}\text { Opaque doors } \\
\quad \text { Swing } \\
\text { Non-swing }\end{array}$ & $\begin{array}{l}3.971 \\
8.226\end{array}$ & & $\begin{array}{l}\text { Partition } \\
\text { wall }\end{array}$ & 1.0 & 1.0 \\
\hline
\end{tabular}

*c.i.: continuous insulation

** C-factor: Time rate of steady-state heat flow through unit area of a material or construction, induced by a unit temperature difference between the body surface $(\mathrm{W} / \mathrm{m} \cdot \mathrm{K})$

*** F-factor: the perimeter heat loss factor for slab-on-ground floors $(\mathrm{W} / \mathrm{m} \cdot \mathrm{K})$ 
Table 10Comparison of window requirements in China standard GB 50189-2014 and U.S. ASHRAE standard 90.1-2013.

\begin{tabular}{|c|c|c|c|c|c|c|c|}
\hline \multirow[b]{3}{*}{$\begin{array}{l}\text { Framing } \\
\text { Type }\end{array}$} & $0.1-2013 / C$ & \multirow[b]{3}{*}{$\begin{array}{l}\text { Maximum } \\
\text { SHGC }\end{array}$} & \multicolumn{5}{|c|}{ GB50189-2014/Cold Zone } \\
\hline & \multirow{2}{*}{$\begin{array}{l}\text { Assembly } \\
\text { maximum } \\
\text { U-factor } \\
\left(\mathbf{W} / \mathbf{m}^{2} \mathbf{K}\right)\end{array}$} & & \multirow[b]{2}{*}{ WWR } & \multicolumn{2}{|c|}{ Shape Coeffcient $\leq 0.3$} & \multicolumn{2}{|c|}{$0.3<$ Shape Coefficient $\leq 0.4$} \\
\hline & & & & $\begin{array}{l}\text { Maximum } \\
\text { U-factor } \\
\left(\mathbf{W} / \mathbf{m}^{2} \mathbf{K}\right)\end{array}$ & $\begin{array}{l}\text { SHGC } \\
(\mathbf{E}, \mathbf{S}, \mathbf{W} / \mathbf{N})\end{array}$ & $\begin{array}{l}\text { Maximum } \\
\text { U-factor } \\
\left(\mathbf{W} / \mathbf{m}^{2} \mathbf{K}\right)\end{array}$ & $\begin{array}{l}\text { SHGC } \\
(\mathbf{E}, \mathbf{S}, \mathbf{W} / \mathbf{N})\end{array}$ \\
\hline \multirow[t]{2}{*}{$\begin{array}{l}\text { Non-mental } \\
\text { framing }\end{array}$} & 1.82 & & $\leq 0.2$ & 3.0 & - & 3.0 & - \\
\hline & & & $0.2-0.3$ & 2.7 & $0.52 /-$ & 2.5 & - \\
\hline $\begin{array}{l}\text { Metal } \\
\text { framing, fixed }\end{array}$ & 2.38 & & $0.3-0.4$ & 2.4 & $0.48 /-$ & 2.3 & $0.588 /-$ \\
\hline \multirow[t]{2}{*}{$\begin{array}{l}\text { Metal } \\
\text { framing, } \\
\text { operable }\end{array}$} & 2.84 & 0.4 & $0.4-0.5$ & 2.2 & $0.43 /-$ & 2.0 & $0.50 /-$ \\
\hline & & & $0.5-0.6$ & 2.0 & $0.40 /-$ & 1.8 & $0.42 /-$ \\
\hline $\begin{array}{l}\text { Metal } \\
\text { framing, } \\
\text { entrance door }\end{array}$ & 4.37 & & $0.6-0.7$ & 2.0 & $0.35 / 0.60$ & 1.8 & $0.42 /-$ \\
\hline
\end{tabular}

Table 11Comparison of LPD requirements in China standard GB 50189-2014 and U.S. ASHRAE standard 90.1-2013.

\begin{tabular}{lc|c}
\hline & ASHRAE $90.1-2013$ & GB50189-2014 \\
\cline { 2 - 3 } & LPD $\left(\mathbf{W} / \mathbf{m}^{2}\right)$ & LPD $\left(\mathbf{W} / \mathbf{m}^{2}\right)$ \\
\hline \hline Office buildings & \\
$\quad$ & \\
Office room & 12.0 & 9.0 \\
$\quad$ Conference room & 13.3 & 9.0 \\
$\quad$ High-class office room & N.A. & 15.0 \\
Hotels & & \\
Guest room & 9.8 & 7.0 \\
Lobby & 11.5 & 9.0 \\
Schools & & \\
Class room & 13.4 & 9.0 \\
Lab & 15.5 & 9.0 \\
Hospitals & & \\
Exam / treatment & 18.0 & 15.0 \\
Operating room & 26.8 & 30.0 \\
Ward room & 6.7 & 5.0 \\
Nurse station & 7.6 & 9.0 \\
Pharmacy & 8.0 & 15.0 \\
\hline
\end{tabular}


Table 12Comparison of chiller efficiency requirements in China standard GB 50189-2014 and the U.S. ASHRAE standard 90.12013.

\begin{tabular}{|c|c|c|c|c|c|c|c|}
\hline & & \multicolumn{3}{|c|}{ ASHRAE $90.1-2013$} & \multicolumn{3}{|c|}{ GB50189-2014 } \\
\hline & & $\begin{array}{c}\text { Cooling } \\
\text { Capacity }(\mathrm{kW})\end{array}$ & $\mathrm{COP}$ & IPLV & $\begin{array}{c}\text { Cooling } \\
\text { Capacity } \\
(\mathrm{kW}) \\
\end{array}$ & $\mathrm{COP}$ & IPLV \\
\hline \multirow{13}{*}{$\begin{array}{l}\text { Water- } \\
\text { cooled }\end{array}$} & \multirow{5}{*}{$\begin{array}{c}\text { Reciprocating/ } \\
\text { Scroll }\end{array}$} & $<264$ & 4.69 & 5.87 & $<528$ & 4.1 & 4.9 \\
\hline & & $264-528$ & 4.89 & 6.29 & & \multirow{4}{*}{ N.A. } & \\
\hline & & $528-1055$ & 5.33 & 6.52 & & & \\
\hline & & $1055-2100$ & 5.77 & 6.77 & & & \\
\hline & & $>2110$ & 6.29 & 7.04 & & & \\
\hline & \multirow{5}{*}{ Screw } & $<264$ & 4.69 & 5.87 & $<528$ & 45 & 545 \\
\hline & & $264-528$ & 4.89 & 6.29 & & 4.5 & 5.45 \\
\hline & & 528-1055 & 5.33 & 6.52 & $528-1163$ & 5.1 & 5.85 \\
\hline & & $1055-2110$ & 5.77 & 6.77 & & & \\
\hline & & $>2110$ & 6.29 & 7.04 & $>1163$ & 5.5 & 6.2 \\
\hline & \multirow{3}{*}{ Centrifugal } & $<1055$ & 5.77 & 6.4 & $<1163$ & 5.2 & 5.35 \\
\hline & & $1055-1163$ & 6.29 & 6.77 & $1163-2110$ & 5.5 & 5.6 \\
\hline & & $>1163$ & 6.29 & 7.04 & $>2110$ & 5.8 & 6.1 \\
\hline \multirow{4}{*}{$\begin{array}{l}\text { Air-cooled } \\
\text { or } \\
\text { evaporative } \\
\text { cooler }\end{array}$} & \multirow{2}{*}{$\begin{array}{l}\text { Reciprocating/ } \\
\text { Scroll }\end{array}$} & $\leq 50$ & 2.4 & N.A. & $\leq 50$ & 2.6 & 3.1 \\
\hline & & $>50$ & 2.6 & N.A. & $>50$ & 2.8 & 3.35 \\
\hline & \multirow[b]{2}{*}{ Screw } & $\leq 50$ & 2.6 & N.A. & $\leq 50$ & 2.8 & 3 \\
\hline & & $>50$ & 2.8 & N.A. & $>50$ & 3 & 3.2 \\
\hline
\end{tabular}

Table 13Comparison of requirements for unitary air conditioners in China standard GB 50189-2014 and U.S. ASHRAE standard 90.1-2013.

\begin{tabular}{|c|c|c|c|c|c|c|c|c|c|c|}
\hline \multicolumn{3}{|c|}{ ASHARE 90.1-2013 } & \multicolumn{8}{|c|}{ GB50189 -2014 COP } \\
\hline & $\begin{array}{l}\text { Cooling } \\
\text { Capacity } \\
(\mathrm{kW})\end{array}$ & $\mathrm{COP}$ & Type & $\begin{array}{c}\text { Cooling } \\
\text { Capacity } \\
(\mathrm{kW})\end{array}$ & $\begin{array}{c}\text { Severe } \\
\text { cold } \\
\text { A/B } \\
\text { zone }\end{array}$ & $\begin{array}{c}\text { Severe } \\
\text { cold C } \\
\text { zone }\end{array}$ & $\begin{array}{c}\text { Temperate } \\
\text { zone }\end{array}$ & $\begin{array}{l}\text { Cold } \\
\text { zone }\end{array}$ & $\begin{array}{c}\text { Hot- } \\
\text { Summer } \\
\text { Cold- } \\
\text { Winter }\end{array}$ & $\begin{array}{c}\text { Hot- } \\
\text { Summer } \\
\text { Warm- } \\
\text { Winter }\end{array}$ \\
\hline \multirow{4}{*}{$\begin{array}{c}\text { Air } \\
\text { cooled }\end{array}$} & $<19$ & 3.81 & \multirow[b]{2}{*}{ Ductless } & $7.1-14$ & 2.70 & 2.70 & 2.70 & 2.75 & 2.80 & 2.85 \\
\hline & $19-40$ & 3.22 & & $>14$ & 2.65 & 2.65 & 2.65 & 2.70 & 2.75 & 2.75 \\
\hline & $\begin{array}{c}40-70 \\
70-223\end{array}$ & $\begin{array}{l}3.16 \\
2.87\end{array}$ & \multirow[t]{2}{*}{ Ducted } & $7.1-14$ & 2.40 & 2.40 & 2.40 & 2.45 & 2.50 & 2.55 \\
\hline & $>223$ & 2.78 & & $>14$ & 2.35 & 2.35 & 2.35 & 2.40 & 2.45 & 2.50 \\
\hline \multirow{4}{*}{$\begin{array}{l}\text { Water } \\
\text { cooled }\end{array}$} & $<19$ & 3.54 & \multirow[b]{2}{*}{ Ductless } & $7.1-14$ & 3.40 & 3.45 & 3.45 & 3.50 & 3.55 & 3.55 \\
\hline & $19-40$ & 3.54 & & $>14$ & 3.25 & 3.30 & 3.30 & 3.35 & 3.40 & 3.45 \\
\hline & $\begin{array}{c}40-70 \\
70-223\end{array}$ & $\begin{array}{l}3.60 \\
3.57\end{array}$ & \multirow[b]{2}{*}{ Ducted } & $7.1-14$ & 2.90 & 2.90 & 2.95 & 3.00 & 3.05 & 3.10 \\
\hline & $>223$ & 3.51 & & $>14$ & 2.80 & 2.80 & 2.85 & 2.90 & 3.00 & 3.00 \\
\hline
\end{tabular}

